\title{
The practice of the ergonomist consultant: a reflexive tools-based approach
}

La pratique de l'intervention d'ergonomes consultants : une approche réflexive orientée par les outils

La práctica de la intervención de los ergónomos consultores: une enfoque

reflexivo orientado por las herramientas

Léonard Querelle and Jean-François Thibault

\section{(Q) OpenEdition}

\section{Journals}

Electronic version

URL: http://journals.openedition.org/activites/1470

DOI: $10.4000 /$ activites. 1470

ISSN: $1765-2723$

\section{Publisher}

ARPACT - Association Recherches et Pratiques sur les ACTivités

\section{Electronic reference}

Léonard Querelle and Jean-François Thibault, « The practice of the ergonomist consultant: a reflexive tools-based approach », Activités [Online], 4-1 | avril 2007, Online since 15 April 2007, connection on 10 December 2020. URL : http://journals.openedition.org/activites/1470 ; DOI : https://doi.org/10.4000/ activites. 1470 


\title{
The practice of the ergonomist consultant: a reflexive tools-based approach
}

\section{Leonard Querelle \& Jean-François Thibault}

\author{
Laboratoire d'ergonomie des systèmes complexes (L.E.S.C.), \\ Université Victor Segalen Bordeaux 2, France. \\ querelle.leonard@orange.fr \\ Jean-Francois.Thibault@ergo.u-bordeaux2.fr
}

\begin{abstract}
This article proposes to analyze the work of the ergonomist consultant in intervention on the basis of a service relationship model. The authors show that the activity of advising is based entirely on a service provision basis. From this point of view, it proves that the service relationship applied to the ergonomic intervention raises the issue of the objects used in the intervention. However, the theoretical outline of the service relationship must be adapted to study the ergonomic intervention. Thus we start from a reflexive point of view on the intervention to test the heuristic dimension of the model and to raise new issues.
\end{abstract}

KEYWORDS:

activity theory, ergonomist practice, service relationship, project control, ergonomic intervention

\section{Introduction}

Everyday, the ergonomist uses tools to carry out his interventions. While these tools result to some extent from the theoretical and practical inheritance of ergonomics, one of the facets of the ergonomist's work is to design, to adapt and to optimize them in order to improve their performance.

As in production of goods, it seems important to approach the concept of performance in the ergonomic intervention (Thibault, 2002) through the tools used by the consultant ergonomist. We will initially approach the ergonomic intervention from the service relationship point of view and show how the tools are used by the consultant ergonomist and why they structure his intervention.

\section{1.- From advising to the service relationship model}

Gadrey (1994) presents advising like the most extreme of the intangible services and regards it as an archetypal relational activity. For him, this activity consists in:

— analyzing a problem encountered by an organization

— proposing solutions or recommendations based on a diagnosis

- taking part in the implementation of the solutions.

In fact, the consultant's practice belongs to the field of the service relationship.

If the founder of the service relationship seems to be Goffman (1968), we reiterate the definition suggested by Gadrey. He defines the service relationship as "an operation aiming at a state transformation of a reality $C$, owned or used by a consumer - customer or user - $B$, realized by a service provider $A$ at the request of $B$ and often in relation with him, but not resulting to the production of a 
good be able to circulate economically, independently of the support C"' (Gadrey, 1992).

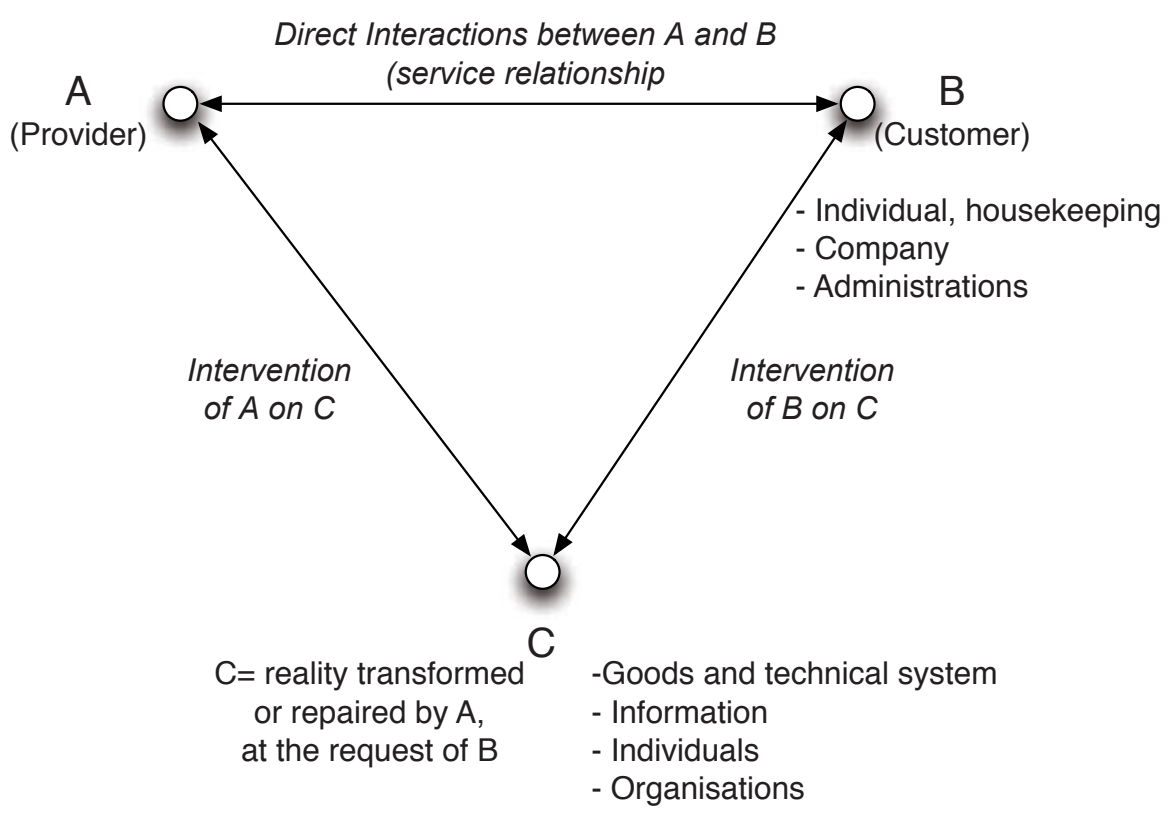

Figure 1: A model of the service relationship

New prospects arise starting from the ideas of Mayen (2005). Indeed, the service provider must deal with two distinct dimensions:

- the object to which the intervention must relate,

- the relationship that the user maintains with this object (often relationship of dependence).

In addition, the commitment of the service provider implies a double activity within situations of management (Jackson, 1998):

- of its intervention on the object but also of the intervention of the customer

- of the service relationship

The representation suggested in Figure 2 is very similar to the consultation triangle of Villette (2003, p. 51).

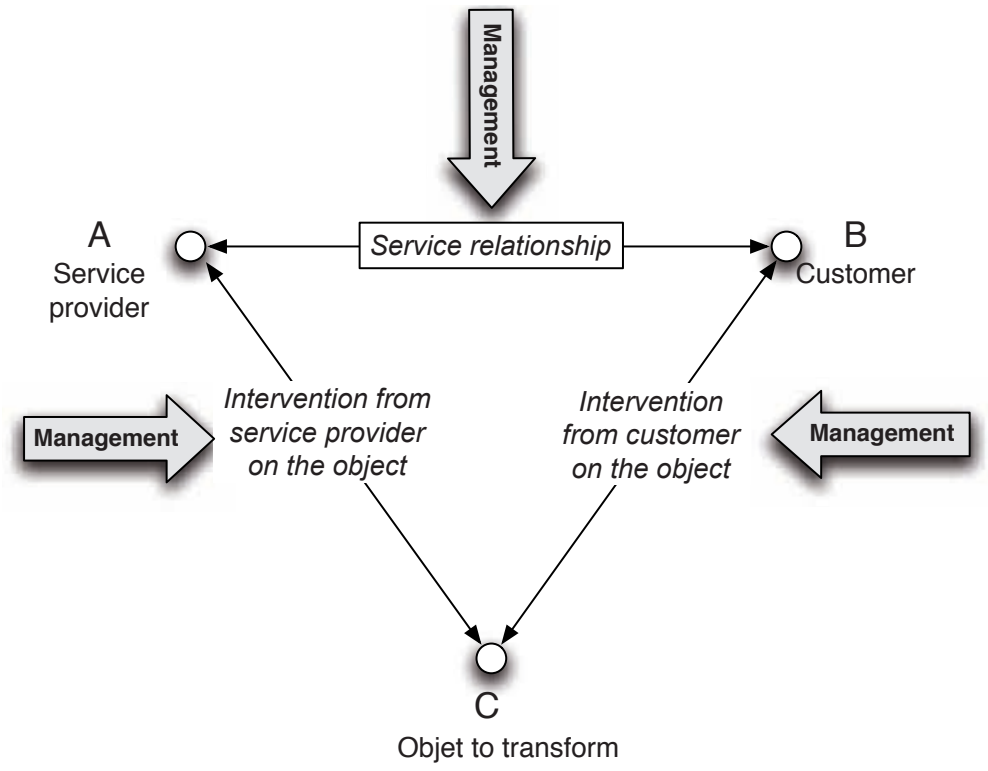

Figure 2: The management of the service relationship 
In this description, the significant element is that one of the objects of the service provider's work can be the relationship between the user and the object to transform. Mayen defends this hypothesis: " not only the professionals of the service have to build a repertory of knowledge relating to the technical object of the service, the relationship maintained by the customer with the object and the social and institutional framework in which is held the transaction of service, but also that these three fields must be closely connected in a system of representation and action integrator. " (Mayen, 2005, p. 63)

In other words, the service customer is part of a socio-economic and institutional context, which influences his strategic action. On the one hand, the service provider must understand all the characteristics of this environment to act. In addition, he depends himself on external elements relating to his own socio-economic and institutional context. These constraints imposed by the contexts of the customer and the service provider are part of the construction of a framework as well as a prescription. The consultant must bring to bear the same vigilance in his intervention of the object as in the intervention of the customer on the same object.

\section{2.- "System of service relationships": prospects for the ergonomic intervention}

Starting from the limits of the above-mentioned model of the service relationship, we will consider an ergonomic model of intervention based on a system of service relationships. Obviously, this system evolves like the intermediate objects used by the ergonomist consultant.

\section{1.-Limits of the model of the service relationship applied to the ergonomic intervention}

In France, many authors discuss the ergonomist's practice within the service relationship model (Hubault, 2001; Cerf, \& Falzon, 2005; Petit, 2005). From these works and from our own experience, we will outline the limitations and propose new perspectives ${ }^{1}$.

Based on the model previously presented (see Figure 2), applied to the ergonomic intervention led to a new second reading of this model. The service provider becomes the ergonomist consultant and the object to be transformed becomes a socio-technical system ${ }^{2}$ whatever the level selected (working station, workshop, factory). From the concept of "service user" (that we prefer to "customer" which is too limited in an economic sense), the debate involves several questions.

Indeed, who can the user of the "ergonomic" service be? In the industrial sector, is this the director of the company, the CEO, the person in charge of production, the supervisor, the operator, even the consumer? In public institutions like hospitals, is it the regional manager, the director of the hospital, the engineer, the head of department, the doctor, the senior staff, the nurse, the assistants or the patient? Already, a certain number of precautions seem necessary regarding this definition.

The daily practice of the consultant involves relationships between the consulting ergonomist (the service provider) and the user (the customer). One of the characteristics of the service relationship is the imbalance between the service provider and the user, who places both of them in a situation where they will be able to produce together what neither one could achieve alone.

If the user can be defined as the actor of the socio-technical system, which is be at one moment " $T$ " in the relationship with the consultant ergonomist, a limitation in the preceding definitions becomes manifest. Indeed, the consulting ergonomist is confronted with a set of actors or users with which he/ she must create and maintain service relationships. The initial definition, which proposed a service

1. These theoretical considerations are developed at length in a thesis in progress by Léonard Querelle

2. We prefer the concept of socio-technical system rather than company. This notion is detached from a legal definition of the company which poses too restrictive a framework. 
relationship addressed to a single customer, cannot no longer be used. Thus, the users are removed from the socio-technical system for two reasons. On the one hand, their network of relationships is distinguished from the other actors, at the moment of the service relationship, by the interaction with the service provider. On the other hand, the nature of these relationships to the socio-technical system dissociates those they have with daily work.

We propose to consider the ergonomic intervention like a system within the terms of Crozier and Friedberg. That is: "the system is a unit of interdependent parts, which thus has a minimum of structuring, which distinguishes it from the simple aggregate, and which lays out, at the same time, mechanisms which maintain this structuring and which one can call mechanisms of regulation". Therefore, the service relationships are integrated in "systems of concrete action" (Crozier, \& Friedberg, 1977, p. 244). Then, this implies that the service relationship is a system of services relationships where the actors are interdependent from each other and must "help" to manage and to produce together the response to the problem encountered.

\section{2.-A system of services relationships like a model of the ergonomic intervention}

To consider the service relationship as a system of services relationships underlines the interdependence of the system's elements. Any modification on one of the elements will have consequences on the whole of the system, as will any decision not to change anything. This dimension makes the work of the ergonomist consultant more complex. More generally, it can explain the profession of consulting which involves services relationships not with an organization or a company, but with users, who themselves act within a socio-technical system that requires changes (the object of the service).

The initial diagram could thus be modified:

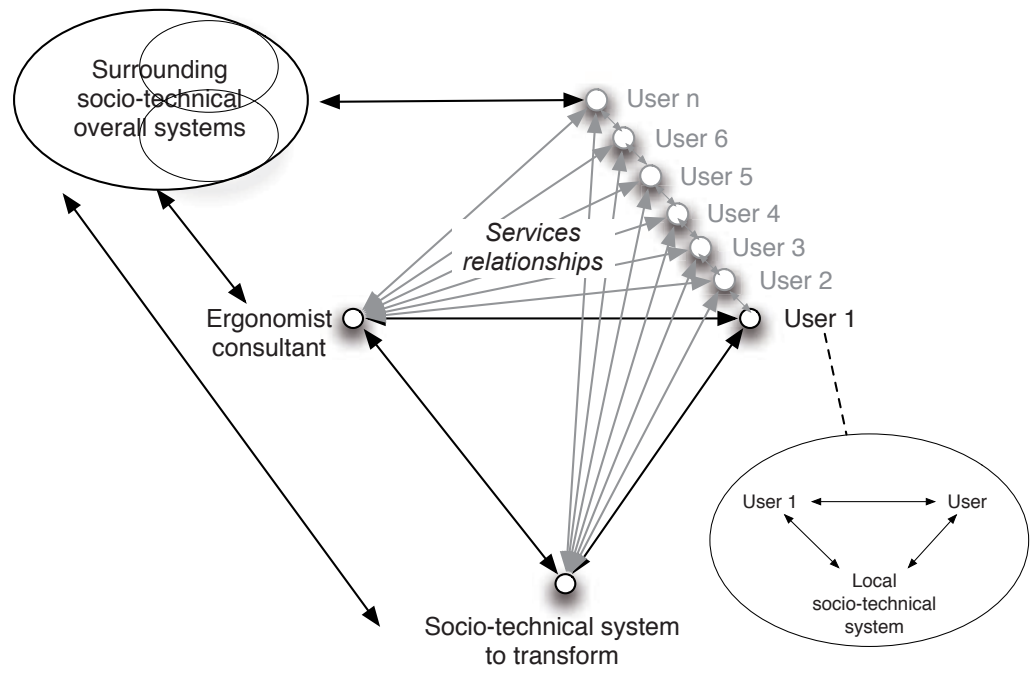

Figure 3: System of services relationships

Part of the consultant ergonomist's work concerns the management of the various types of relationships (see Figure 3) inherent in the service provided:

- Relationships of "users" with the socio-technical system to transform like those relating to the functions of strategic and operational management.

- Relationships of users between themselves in their project functions: for example, (project manager, designers, industrialization manager, ...)

- Relationships of the "users" with the consultant ergonomist as a service provider (customer, 
supplier of technical elements ...)

- Relationships of the consultant ergonomist with the socio-technical system to be changed, object of the service (analyses of situations, drawing up specifications, simulations,).

- Relationships of the consultant ergonomist with the surrounding socio-technical systems, which specify its position.

- Relationships of the socio-technical system to transform with the surrounding socio-technical systems defining the general context of the ergonomic intervention; (for example, an ergonomic intervention with a social plan differs completely from an intervention within an investment project).

From this point of view, the co-construction (service provider - users) of the consultant ergonomist's position within an industrial and/or architectural project control is structured on one hand by the services relationships. For example, the functions of strategic and operational management associated to the four families of criteria of project management (Thibault, 2000) fit perfectly in this services relationships model, which the consultant ergonomist will implement during his ergonomic intervention.

The prospect for social construction (Thibault, 2002; Daniellou, 2005,) inevitably will multiply the number of users of the ergonomic intervention and consequently will multiply the number of services relationships. Moreover, these relationships do not pre-exist the intervention, they are constituted progressively as the intervention advances.

\section{3.-Temporal dimension and intermediate tools}

Like any constructive approach, the ergonomic intervention proceeds in stages over time. Indeed, the intervention differs with the project's temporality. Moreover, from the beginning to the end of the intervention, the users will evolve and generally some new ones appear, thus modifying the situations of management.

This temporal dimension involves, on the one hand, a dynamic and evolutionary aspect of services relationships. Indeed, any attempt to represent this model is valid only at one moment " $T$ ".

In addition, this temporal dimension also involves the concept of the socio-technical system to be changed. Indeed, if "the final object" of the service is the change or the design of a socio-technical system, it is never directly the object of work during the intervention. As shown by Jeantet, Tiger, Vinck and Tichkiewitch (1996), the design rests on intermediate objects, which will make it possible to bring the unit or part of the users to work on the unit or part of the elements to be designed.

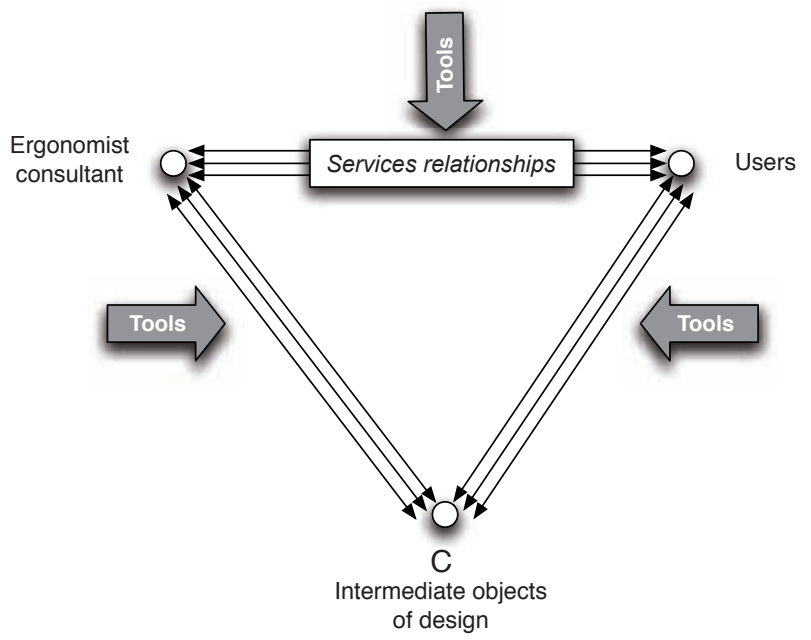

Figure 4: Proposal for a model of the ergonomic intervention 
We propose a representation of the ergonomic intervention seen as a system (see Figure 4). "The intervention system" is simultaneously outside and inside the socio-technical system. To some extent, the intervention is carried out in the time and the place of the company concerned, but it is marked by all the experience of the consultant and even by the team of consultants, if one is involved. Moreover, it is prepared outside the company. One can draw a parallel between what binds these two "times" and the link between "front office" and "back office" discussed by Petit (2005).

The ergonomic intervention has an effect only on part of the project. The decision-makers of the socio-technical system (chairman, industrial directors, project leaders...) are the actors who have the final decision in the intervention. Inside actors (operators, frameworks of proximity...) will be mobilised as a resource in the intervention and this has effects on the unit of the socio-technical system. The project remains an element of the company subjected to the direct influence of the set of internal actors.

The consultant is an external actor among others with whom the set must often cooperate. The consultant designs or transforms intermediate objects adapted to the situation and the objectives of the intervention. If these intermediate objects of design are classical such as diagrams, plans and schedules, they can also be entirely designed by the consultant during his/her intervention.

\section{3.- Examples of tools used by the consulting ergonomist}

The consultant implements several types of tools structuring the system of services relationships. Here we discuss the example of a project management tool.

\section{1.-Two categories of the consultant ergonomist's tools in the system of services relationships}

In our practice of consultant ergonomist, we use tools which structure our service (see Figure 5) (Thibault, 2002; Querelle, \& Escoutelou, 2005). On the basis of the model previously explained, these tools can be classified in two categories:

- tools supporting services relationships,

— tools supporting the structuring of intermediate design objects .

- Obviously, these tools can change over time while being temporarily part of the project. These tools make it possible to provide reference marks of various types for the users:

— prescriptive (for example, reference to ergonomic standards in specifications)

- descriptive (for example, simulations of work situations and updates of their determinants)

- procedural (for example, planning of the ergonomic intervention adjusted to overall project planning)

Thus, they also ensure part of the traceability of the ergonomic intervention and provide the support for performance evaluation of the intervention.

We consider the use of tools by the consultant within the framework of a model of performance evaluation (Thibault, 2002) insofar as the tools:

— are collectively shared and constitute a common operative reference framework

- evolve within a dynamic of social construction in and by the ergonomic intervention

- are built, validated and used as performance indicators

- are mediators in the relationships between the strategic and operational management of the project 


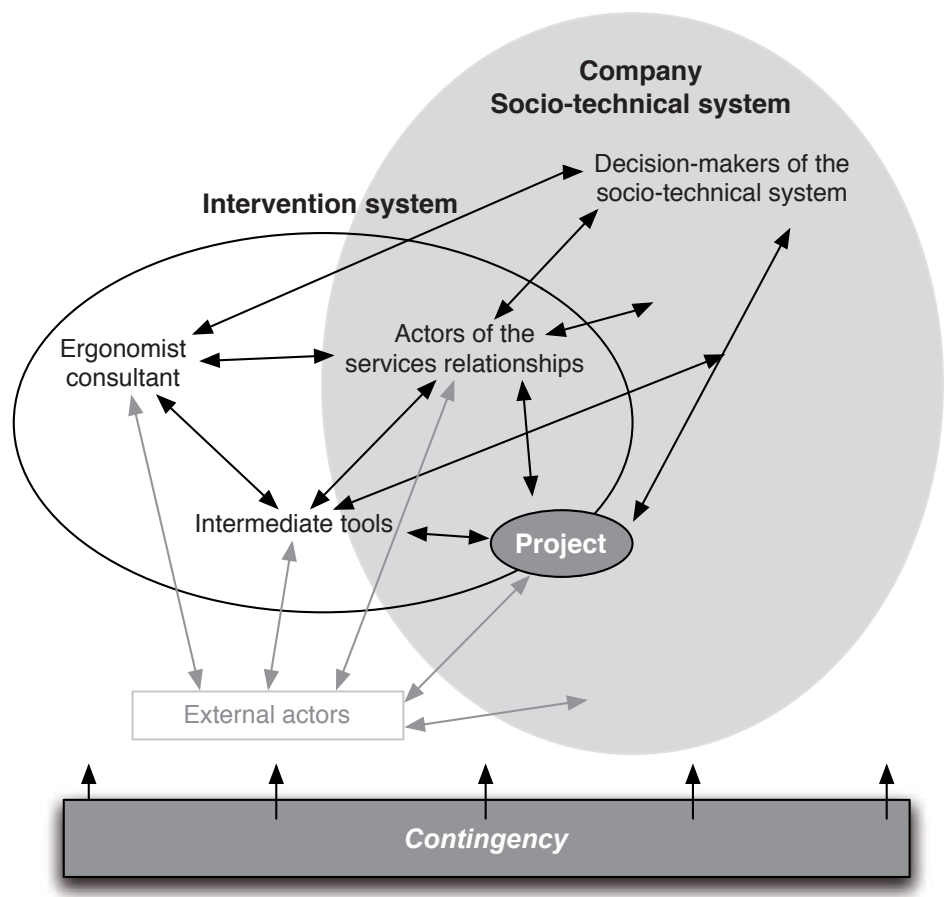

Figure 5: Intermediate tools of consulting in the system of services relationships

The consultant manages these tools during the intervention and decides how they are to change. His/ her work lies at the heart of a transversal integration of information and modes of communication that structure the services relationships and the intermediate objects of design. This notion harks back to the notion of project management in concurrent engineering, i.e. "integration of data" (Durand, 2004). For data to be integrated, the same information is shared and exchanged between the various functions of the company.

\section{2.-Illustration of a management tool}

The tools for simulations used by ergonomist (plans, models, etc) made the object of many research and publications, which show the importance of this category of tool as an intermediate object of the design. We thus chose to illustrate this article with a management tool rather, namely "the monitoring document of industrial project", and by showing how this tool that we use in intervention makes it possible to structure our services relationships with the various actors of the project.

\begin{tabular}{|c|l|l|c|}
\hline \multicolumn{4}{|c|}{ Task: Cutting fillet of fish } \\
\hline $\begin{array}{c}\text { Work } \\
\text { situation }\end{array}$ & \multicolumn{1}{|c|}{ Remarks } & \multicolumn{1}{|c|}{ Landmark design } & State* $^{*}$ \\
\hline $\begin{array}{l}\text { Sharpening } \\
\text { knifes }\end{array}$ & $\begin{array}{l}\text { Blade wear varies } \\
\text { with cutting gesture, } \\
\text { fish thckness }\end{array}$ & $\begin{array}{l}\text { Create a dedicated } \\
\text { room adjoining to the } \\
\text { cutting shop }\end{array}$ & $\mathrm{R}$ \\
\hline
\end{tabular}

*: $R$ : réalisé, $E$ : étude en cours ; $A$ : abandon

Figure 6: Monitoring document of industrial project

The monitoring document ${ }^{3}$ for an industrial project (see Figure 6) is written and updated by the er-

3. For more precise details on this tool, see the presentation of Thibault (2002) at the SELF congress. 
gonomist throughout the intervention. The structure of the document includes the various situations of work classified according to sector or workshop. It is based on the analysis of the work carried out by consultant and includes the data resulting from the analysis of existing work situations and future ones. The document is used to change existing sites and in the design of new installations.

The major interest of this type of tool is to structure and share information:

- It makes it possible for each actor, present or not during meetings, to keep track of the project, the design decisions and to identify the points remaining to be cleared up. The actors are able to raise points with the ergonomist and to anticipate work still remaining to be done.

- During these phases of preparation, the actors are informed how the information will be presented and used. This tool is thus a facilitator during the phases of preparation and simulation before instructions are finally given. During the latter phase, the decisions are taken on the basis of all the elements or points raised by the actors of the company and the service provider.

- This tool also allows the ergonomist, who is participating in several projects at the same time, to come back to the project at a later date, since all he/she needs to do is reopen the indicator panel, consult the topic concerned and check the decisions already taken and the points still requiring attention.

- The indicator panel that all attendees at each meeting receive also makes it possible to circulate information within the company without the direct intervention of the ergonomist. In this way, absent or representative authorities can always keep up to date on decisions taken, their implications and their limitations.

- This framework opens prospects for evaluation. It makes it possible to enter the number of elements studied in the project and to compare them with the number of elements implemented by the decision-makers. It represents a trace of the ergonomist's work, making it possible to quantify and qualify the cost effectiveness of the intervention.

This type of tool structures the services relationships, which the ergonomist maintains with the various sectors in the company (owner, human resources, engineering, methods, safety, etc) and with external service providers (e.g. suppliers, architects, control office, etc.) so that each actor can incorporate information relating to the intervention. With the support of data-processing tools, the document is easily transmitted and modified. In fact, one could here coin the term "appropriation capability" to describe the usefulness of the document. In this way, it regularly becomes the company document according to which the project leader coordinates various levels of assigning tasks, and making decisions.

\section{4.- Conclusion}

In the ergonomic intervention, the ergonomist is confronted with many actors and interlocutors. On the one hand, this creates difficulties with regard to the number of management variables; on the other, however, it contributes to the performance of the ergonomic intervention. Thus, the co-production of services relationships and intermediate objects necessarily involves a number of actors. The consultant must permanently handle individual and collective dimensions that are both resources and difficulties; moreover, you cannot always "do it the same way". He/she thus implements tools which, throughout their life cycle, mediate the design process and help to organise the social relationships between the actors involved.

This analysis of the ergonomic intervention in terms of reflexive practise also demonstrates that by observing the ergonomist's work from the angle of a system of services relationships, the profession can be seen as one in which advice is given as much as situations are analysed. Of course, this notion 
of the dual function of the ergonomist-adviser deserves more attention in fields not discussed in this article, such as the commercial relationships in which the ergonomist is involved. This viewpoint suggests further approaches in the teaching of the profession of ergonomist.

\section{REFERENCING}

Querelle , L., \& Thibault, J.-F. (2007). The practice of the ergonomist consultant: a reflexive tools-based approach.@ctivités, 4 (1), pp.160-169, http://www.activites.org/v4n1/v4n1.pdf.

\section{REFERENCES}

Cerf, M., \& Falzon, P. (Eds.) (2005). Situations de service : travailler dans l'interaction. Paris: PUF.

Crozier, M., \& Friedberg, E. (1977). L'acteur et le système. Paris: Seuil.

Daniellou, F. (2005). The French-speaking ergonomists' approach to work activity: cross-influences of field intervention and conceptual models. Theoretical Issues in Ergonomics Science, 6 (5), 405-427

Durand, J.P. (2004). La chaîne invisible. Paris: Seuil.

Falzon, P., \& Lapeyrière, S. (1998). L'usager et l'opérateur : ergonomie et relation de service. Le travail humain, 61 (1), 69-88.

Gadrey, J. (1994). Les relations de service dans le secteur marchand. In J. de Bandt, \& J. Gadrey (Eds.), Relations de service, marchés de services (pp. 23-41). Paris: CNRS Éditions.

Goffman (1968). Asiles. Paris: Éditions de Minuit.

Hubault, F. (Ed.) (2001). La relation de service, opportunités et questions nouvelles pour l'ergonomie. Toulouse: Octarès Éditions.

Jackson, M. (1998). Entre situations de gestion et situation de délibération : l'action de l'ergonome dans les projets industriels. Thèse de doctorat d'Ergonomie. Paris: Laboratoire d'Ergonomie du CNAM.

Jeantet, A., Tiger, H., Vinck, D., \& Tichkiewitch, S. (1996). La coordination par les objets dans les équipes intégrées de conception de produits. In G. de Terssac, \& E. Friedberg (Eds.), Coopération et conception (pp. 87-100). Toulouse: Octarès Éditions.

Mayen, P. (2005). Travail de relation de service, compétences et formation. In M. Cerf, \& P. Falzon (Eds.), Situations de service : travailler dans l'interaction (pp. 61-83). Paris: PUF.

Petit, J. (2005). Organiser la continuité du service: Intervention sur l'organisation d'une Mutuelle de santé. Thèse de doctorat d'Ergonomie. Bordeaux: Université Victor Segalen Bordeaux 2.

Querelle, L., \& Escouteloup, J. (2005). The tribulations of an ambulatory sector. In R. Tartaglia, \& S. Bagnara (Eds.), Healthcare systems ergonomics and patient safety: Human Factor, a bridge between care and cure (p.314-317). Londres: Taylor \& Francis.

Thibault, J.-F. (2000). Practice of ergonomics management in industrial design. In "Ergonomics for the new millennium", IEA 2000, XIVth Triennal congress and human factors and ergonomics society, San Diego, USA, pp.297-299.

Thibault, J.-F. (2002). Quand le processus de prescription reflète la performance de l'intervention ergonomique. In J.-M. Evesque, A.-M. Gautier, Ch. Revest, Y. Schwartz, \& J.-L. Vayssière (Eds.), Les évolutions de la prescription (pp. 370-375). Aix-en-Provence: GREACT et SELF.

Villette, M. (2003). Sociologie du conseil en management. Paris: Éditions La Découverte (Collection Repères). 


\section{RÉSUMÉ}

La pratique de l'intervention d'ergonomes consultants : une approche réflexive orientée par les outils. Cet article propose d'analyser le travail de l'ergonome consultant en intervention en partant d'un modèle théorique de la relation de service. En effet, les auteurs de ce modèle montrent que l'activité de conseil repose sur une relation de service à part entière. Dans cette perspective, il s'avère que la relation de service appliquée à l'intervention ergonomique ouvre la discussion sur les objets utilisés dans l'intervention. Cependant il est nécessaire d'adapter les contours théoriques de la relation de service pour étudier l'intervention ergonomique. C'est donc à partir d'une démarche réflexive sur la pratique de l'intervention par des ergonomes consultants que nous avons éprouver la dimension heuristique d'un tel modèle et esquisser de nouvelles perspectives.

\section{Mots-CLEFS}

Théorie de l'activité, relation de service, conduite de projet, modèle d'intervention ergonomique

\section{RESUMEN}

La práctica de la intervención de los ergónomos consultores: une enfoque reflexivo orientado por las herramientas. Este artículo se propone analizar el trabajo del ergónomo consultor que realiza intervenciones, partiendo de un modelo teórico de la relación de servicio. En efecto, los autores de este modelo muestran que la actividad de consultoría reposa enteramente sobre una relación de servicio. En este sentido, se constata que la relación de servicio aplicada a la intervención ergonómica abre la discusión acerca de los objetos utilizados en la intervención. Sin embargo, para estudiar la intervención ergonómica, se hace necesario adaptar los contornos teóricos de la relación de servicio. Por lo tanto, será a partir de un acción reflexiva acerca de la práctica de intervención de los ergónomos, que pondremos a prueba la dimensión heurística de tal modelo, así como bosquejar nuevas perspectivas.

\section{Palabras-clave}

Teoría de la actividad, relación de servicio, conducción de proyectos, modelo de intervención ergonómica. 